\title{
Hypoglycemic and Biochemical Effects of some Medicinal Plant Extracts on Alloxan Induced Diabetic Rats
}

\author{
Othman Ali Othman \\ Chemistry Department (Biochemistry), Faculty of Science, Minia University, El-Minia, Egypt
}

\begin{abstract}
Hypoglycemic and biochemical effects of some mixed medicinal plant extracts were tested on alloxan diabetic rats. The studied extracts were a mixture of Ambrosia maritima, Trigonella-foenum Graecum, and Centraurium - Spicatum, (extract 1), Lupinus albus, Nigella sativa and Gum arabbia (extract II) and Aloe-Ferox and Peganum-harmala (extract III). The hypoglycemic activity of the plant extracts was compared with the hypoglycemic effect of the synthetic drug substance repaglinide [NovoNorm tablets 2 mg repaglinide (Novo Nordisk)]. Male albino rats of the Sprague-Dowely strain weighing about 100 gram were used in the present study and blood samples were collected at zero time (before treatment) and then after 6, 12 and 24 hours from treatment. Blood samples were subjected to biochemical analyses such as blood glucose, liver function, kidney function and lipid profile. Extract 1 exhibited the higher hypoglycemic activity, while extracts II and III induced the lower hypoglycemic activity. The abnormal increase in the mean values of creatinine, urea, aspartate-aminotransferase (AST), alanine-aminotransferase (ALT), triglycerides (TG) and total cholesterol in the induced diabetic rats was greatly improved by each of the three plant extracts.
\end{abstract}

Keywords: Medicinal plant, Hypoglycemic, Transaminase, Repaglinide

\section{Introduction}

Diabetes has been well known as a wasting disease due to insulin deficiency in human. The ancient Indian literature of the prechristian era have distinctly recorded the most important symptoms of this disease. Some of the earlier workers mentioned the use of herbal and mineral preparations for treatment of this disease. It was found of 42 plants which are considered to be useful in treatment of diabetes (1).

Thus medicinal plants continue to provide valuable therapeutic agents, both in modern and traditional medicine $(2-5)$. Noteworthy most of the plants and herbs are rich in the fiber content which is responsible for their hypoglycemic effect, therefore, the addition of certain forms of dietary fibers to the diet of diabetic subjects significantly decreased post-prandial hyperglycemia and is expected to improve and control the blood glucose concentration (6).

It is indicated that, the lactuavirosal (lebbin), Aloe (sabir), Ambrosia maritima (Damsisa), Geranum robertinanum L, (requemoya) and Myrrh exerted an obvious hypoglycemic effect after treatment of the alloxan diabetic rats $(7,8)$.

They are found that, Trigonella-foenium graecum prevented glucosurea in mild diabetes and improved sever diabetes in human. Despite of the hypoglycemic effect of fenugreek seeds and their major alkaloid trigonilline, there has been a renewed interest in these seeds $(9,10)$. A considerable medical interest exists in the use of volatile oil extracted from Nigella sativa producing a significant consistent decrease of blood glucose level in alloxan-diabetic rats $(11,12)$.

Our study is planned to examine the new hypoglycemic agents from natural products, hopefully to minimize the side effects and improve the diabetic condition.

\section{Material and methods}

\section{1) Experimental animal}

In the present study 112 of albino male rats weighing about $100 \mathrm{gm}$ were obtained from the animal house of the Assuite university. The rats were housed in cages with eight animals each at random. They were given the regular laboratory stock diet and evaluated after overnight fasting for the predose blood analysis of glucose, total proteins, urea creatinine, aspartate-aminotransferase (AST), alanineaminotransferase (ALT), triglycerides, and total cholesterol using standard analytical methods. The analysis of these compounds was also performed in all rats at the end of seven days from the treatment. The rats received a single subcutaneous injection of 40,80, 120 and $140 \mathrm{mg}$ alloxan per $\mathrm{kg}$ body weight separately, each in $0.2 \mathrm{ml}$ saline solution respectively. The blood glucose level of each rat was estimated at intervals of 1,2 and 3 days. Another four groups received a single intragastric intubation dose of $1.5 \mathrm{ml}$ from plant extract I, extract II, extract III and NovoNorm tablets (2 mg Repaglinide). The blood glucose levels were measured both prior to the introduction of the dose and after 6,12 and 24 hours.

\section{2) Plant extracts}

Three plant mixture were prepared; ( 5 gm seeds dry weight) from each examined plant in the mixture of Ambrosia maritima (Damsisa), Trigonella-foenum Graecum (Hulba), and Centraurium - Spicatum (Hashishet el acrab), (extract 1), Lupinus albus (Termis), Nigella sativa (Habet el baraka) and Paswella carterii (Gum arabbia) (extract II) and AloeFerox (Sabir) and Peganum-harmala (Harmal) (extract III). Each plant was finely ground then the prepared mixtures were separately boiled with distilled water $(100 \mathrm{ml})$ for 10 minutes. 


\section{International Journal of Science and Research (IJSR) \\ ISSN (Online): 2319-7064}

Index Copernicus Value (2013): 6.14 | Impact Factor (2015): 6.391

\section{3) Blood samples}

They were collected at zero time (before treatment) and then 6, 12 and 24 hours after the treatment. Blood samples were subjected to biochemical analysis concerning blood glucose, liver function, kidney function and lipid profile

\section{4) Biochemical examinations}

Serum total proteins was determined according to the method described by Doumas (1975) (13), blood sugar by Trinder (1969) (14), AST and ALT by Reitman and Frankel (1957) (15), urea by Patton, (1977) (16), creatinine by Henry (1974) (17), triglycerides by Young, and Pestaner (1975) (18) and cholesterol by Deeg, and Ziegenohm (1982) (19).

\section{5) Statistics}

Results are represented as mean \pm standard deviation (S. D). A two way analysis variance (ANOVA) was calculated according to Mason (1976) (20) for testing the significance between various treated groups.

\section{Result and Discussion}

The present data demonstrate that, the subcutaneous injection of rats with 40 or $80 \mathrm{mg}$ alloxan $/ \mathrm{kg}$ body-weight was not enough to induce diabetes in these rats and their blood glucose levels were within normal range $(92 \pm 6.1 \mathrm{mg} / \mathrm{dl})$ and $(110 \pm 4.2 \mathrm{mg} / \mathrm{dl})$ respectively, while the injection of rats with $120 \mathrm{mg}$ alloxan $/ \mathrm{kg}$ body-weight lead to a moderate diabetic rats $(240 \pm 5.1 \mathrm{mg} / \mathrm{dl})$ (Table 1$)$. These results are in agreement with those reported data before who used $120 \mathrm{mg} / \mathrm{kg}$ body weight to produce moderate diabetic rats $(268 \mathrm{mg} / \mathrm{dl}, 238$ $\mathrm{mg} / \mathrm{dl}$ and $270 \mathrm{mg} / \mathrm{dl}$, respectively). Injection with $140 \mathrm{mg}$ alloxan $/ \mathrm{kg}$ body weight led to a sever diabetic rats (410 $\mathrm{mg} / \mathrm{dl})$ and the rats were died within four days $(21,22,23)$.

Extract 1 induced the higher hypoglycemic activity after 24 hours $(167 \pm 4.5 \mathrm{mg} / \mathrm{dl})$. While extracts II and III exhibited lower hypoglycemic activity Table (2).

There was a significant increase in the mean value of serum creatinine $(3.6 \pm 0.5 \mathrm{mg} / \mathrm{dl})$, urea $(98.6 \pm 4 \mathrm{mg} / \mathrm{dl})$, AST $(82.6 \pm 7$ $\mathrm{U} / \mathrm{ml})$, ALT $(76.4 \pm 5 \mathrm{U} / \mathrm{ml})$, triglycerides $(236.1 \pm 11 \mathrm{mg} / \mathrm{dl})$ and total cholesterol $(280.3 \pm 11 \mathrm{mg} / \mathrm{dl})$ of the diabetic rats as compared with the normal rats (Table 3 ). These results were compatible with those who found that the liver was necrotized in alloxan diabetic rats. This supports the view that the hypoglycemic phase of alloxan poisoning may be the result of liver damage. Therefore the high levels of transaminase enzymes found in this study may be due to hepatotoxic effect of alloxan $(8,24)$.
On the other hand, serum from rats treated by extracts I; II and III showed significant decrease in the mean values of creatinine $(1.06 \pm 0.08,1.11 \pm 0.1,1.13 \pm 0.2 \mathrm{mg} / \mathrm{dl})$, urea $(55.4 \pm 6,58.1 \pm 6,61.3 \pm 5 \mathrm{mg} / \mathrm{dl})$, AST $(43.2 \pm 4,54.1 \pm 4$, $56.2 \pm 5 \mathrm{U} / \mathrm{ml})$, and $\operatorname{ALT}(48.4 \pm 2,45.3 \pm 4,52.2 \pm 8 \mathrm{U} / \mathrm{ml})$. After treatment with herbal extracts and repaglinide (synthetic drug), a clear improvement in the triglycerides and total cholesterol levels was recorded (Table 3).

Many natural products are promoted to improve the health status of patients with diabetes. The results concerning the effect of extracts of the plants under study on blood glucose of alloxan induced diabetic rats are in agreement with those of found that the presence of sesquiterpene lactones in damsisa act as a hypoglycemic agents $(7,25)$. Also it was reported that Ambrosia maritima extracts produced significant hypoglycemic effect on the diabetic rats due to the presence of the sesquiterpene lactones, damsin, ambrosin, hymenin as well as umbelliferone and flavonoids (27). Furthermore, they found that damsisa increased the level of serum insulin in the diabetic rats (8).

They are found that the Aloe forex significantly reduce blood sugar levels in diabetic rats and increased the levels of serum insulin in the same rats due to the major constituents of alkaloids, nicotinic acid, coumarine and scopletin $(7,8)$.

Trigonella-foenum graecum seeds exert mild and transient hypoglycemic effect. Also it was noticed that, Trigonella prevents glucosuria in mild diabetes and improves sever diabetes in human (28). It described the hypoglycemic effect of Trigonella seeds which may be due to their major alkaloid trigonillin, and suggested the, antidiabetic effect of Trigonella may be due to, at least in part, to intestinal glucosidase inhibition. Also, it proved that the addition of 4 hydroxyisoleucine extracted from Trigonella seeds on isolated rat pancreas in the presence of $8.3 \mathrm{mM}$ glucose increased the secretion of insulin $(29,30,31)$.

Lupinus albus was found to decrease the blood glucose levels of rats. The hypoglycemic effect of Lupinus albus is due to its content of alkaloids which also significantly impaired the protein utilization $(25,7)$.

The present study revealed that the effect of (extract 1), (extract II) and (extract III) showed a significant hypoglycemic effect as shown in Table (2), when administered orally to alloxan induced diabetic rats.

Table 1: Effect of alloxan on the glucose level of the tested normal rats

\begin{tabular}{|l|l|l|l|l|}
\hline \multirow{2}{*}{$\begin{array}{c}\text { Mean Glucose } \\
\text { levels in normal } \\
\text { rats (mg/dl) }\end{array}$} & \multirow{2}{*}{$\begin{array}{c}\text { Alloxan dose } \\
(\mathrm{mg} / \mathrm{kg} \text { Body } \\
\text { Weight }\end{array}$} & \multicolumn{3}{|c|}{$\begin{array}{c}\text { Mean Blood glucose levels in normal rats (mg/dl) after } \\
\text { injection of alloxan }\end{array}$} \\
\cline { 3 - 5 } & \multicolumn{1}{|c|}{1 day } & 2 days & 3 days \\
\hline $85 \pm 5.1(8)$ & 40 & $92 \pm 6.1$ & $110^{*} \pm 4.2$ & $112^{*} \pm 9.3$ \\
\hline $79 \pm 6.7(8)$ & 80 & $110^{*} \pm 2.3$ & $116^{*} \pm 6.2$ & $120^{*} \pm 3.6$ \\
\hline $84 \pm 3.5(8)$ & 120 & $240^{*} \pm 5.1$ & $255^{*} \pm 3.1$ & $278^{*} \pm 6.8$ \\
\hline $88 \pm 4.1(8)$ & 140 & $385^{*} \pm 7.1$ & $395^{*} \pm 6.2$ & $410^{*} \pm 3.5$ \\
\hline
\end{tabular}

Result Mean \pm S.D

* Significant $\mathrm{p}<0.05$

(8) Number of rats in each group 


\section{International Journal of Science and Research (IJSR) \\ ISSN (Online): 2319-7064}

Index Copernicus Value (2013): 6.14 | Impact Factor (2015): 6.391

Table 2: Effect of plant extracts and repaglinide on the blood glucose levels of the alloxan induced diabetic rats

\begin{tabular}{|c|c|c|c|c|c|}
\hline \multirow[t]{2}{*}{$\begin{array}{c}\text { Tested } \\
\text { Treatment }\end{array}$} & \multirow{2}{*}{$\begin{array}{c}\text { Glucose levels } \\
\text { in normal rats } \\
(\mathrm{mg} / \mathrm{dl})\end{array}$} & \multirow{2}{*}{$\begin{array}{c}\text { Glucose levels } \\
\text { in control } \\
\text { diabetic rat } \\
(\mathrm{mg} / \mathrm{dl})\end{array}$} & \multicolumn{3}{|c|}{$\begin{array}{c}\text { Mean glucose levels of alloxan induced diabetic rats } \\
\text { after treatment } \mathrm{mg} / \mathrm{dl}\end{array}$} \\
\hline & & & 6 hours & 12 hours & 24 hours \\
\hline Extract I & $87 \pm 6.2$ & $245^{*} \pm 9$ & $195^{*} \pm 3$ & $180^{*} \pm 7.1$ & $167^{*} \pm 4.5$ \\
\hline Extract II & $84 \pm 3.4$ & $255^{*} \pm 8$ & $233^{*} \pm 8$ & $202^{*} \pm 9.2$ & $175^{*} \pm 6.5$ \\
\hline Extract III & $78 \pm 7.1$ & $248^{*} \pm 6$ & $238^{*} \pm 3$ & $205^{*} \pm 11$ & $185^{*} \pm 7.4$ \\
\hline Repaglanide & $86 \pm 5.2$ & $257^{*} \pm 2$ & $199^{*} \pm 5$ & $190^{*} \pm 8.1$ & $180^{*} \pm 6.5$ \\
\hline
\end{tabular}

Table 3: Effect of treatment with plant extracts and repaglinide on the concentration of total protein, urea, creatinine, AST, ALT, triglyceride and cholesterol of the alloxan induced diabetic rats

\begin{tabular}{|c|c|c|c|c|c|c|c|}
\hline & $\begin{array}{c}\text { Total proteins } \\
\mathrm{mg} / \mathrm{gm}\end{array}$ & $\begin{array}{c}\text { Urea } \\
\mathrm{mg} / \mathrm{dl}\end{array}$ & $\begin{array}{c}\text { Creatinine } \\
\mathrm{mg} / \mathrm{dl}\end{array}$ & $\begin{array}{c}\text { AST } \\
\mathrm{U} / \mathrm{ml}\end{array}$ & $\begin{array}{c}\text { ALT } \\
\mathrm{U} / \mathrm{ml}\end{array}$ & $\begin{array}{c}\text { Triglycerides } \\
\mathrm{mg} / \mathrm{dl}\end{array}$ & $\begin{array}{c}\text { Total } \\
\text { Cholesterol } \mathrm{mg} / \mathrm{dl}\end{array}$ \\
\hline Normal rats & $125.4 \pm 4.5$ & $28.2 \pm 1.5$ & $0.52 \pm 0.45$ & $23.4 \pm 3$ & $28.8 \pm 3$ & $116.4 \pm 5.7^{*}$ & $165.2 \pm 7.3$ \\
\hline Control diabetic rats & $75.6^{*} \pm 9.1$ & $98.6^{*} \pm 3$ & $3.6^{*} \pm 0.5$ & $82.6^{*} \pm 7$ & $76.4^{*} \pm 5$ & $236.1^{*} \pm 11$ & $280.3^{*} \pm 11$ \\
\hline Extract I & $118^{*} \pm 8.5$ & $55.4^{*} \pm 6$ & $1.06^{*} \pm 0.08$ & $43.2^{*} \pm 4$ & $48.4^{*} \pm 2$ & $195.7^{*} \pm 6.1$ & $195.6^{*} \pm 7.6^{*}$ \\
\hline Extract II & $108.6^{*} \pm 4.5$ & $58.1^{*} \pm 6$ & $1.11^{*} \pm 0.1$ & $54.1^{*} \pm 4$ & $45.3^{*} \pm 4$ & $190.3^{*} \pm 7$ & $205^{*} \pm 9.8^{*}$ \\
\hline Extract III & $120.1^{*} \pm 3.5$ & $61.3^{*} \pm 5$ & $1.13^{*} \pm 0.2$ & $56.2^{*} \pm 5$ & $52.2^{*} \pm 8$ & $200.2 \pm 4.5$ & $201^{*} \pm 8.6$ \\
\hline Repaglinide & $112.4^{*} \pm 9.5$ & $60.2^{*} \pm 9$ & $1.8^{*} \pm 0.4$ & $57.3 \pm 4$ & $40.3^{*} \pm 4$ & $196.1^{*} \pm 9.6$ & $198^{*} \pm 9.4$ \\
\hline
\end{tabular}

Result Mean \pm S.D

*Significant $\mathrm{p}<0.05$

\section{References}

[1] Nadkarins, KM. (1954): Indian Material Medica, $3{ }^{\text {rd }}$ ed. revised and enlarged by A.K. Nadkarins, Popular book Depot Bombay, 2 vols.

[2] Saleh, M.R.I. and Gharbo, S. (1963): "Isolation of a crystalline "Alexandrin" from the leaves of centaurea alexaqndrina". J. Pharm. Sci. U.A.R. 4: 17.

[3] Hifny, S.A. and El-Moghazy, S.A.M. (1966): "The study of the root Zygophyllum coccineum". L. Part 1. The chemistry. J. Pharm. Sci. U.A.R. 7: 117.

[4] Freench, D.H. (1971): "The biology and chemistry of the Umbelliferone" Heycuood, V.H. editor. Linnean. Soc. London. Academic press London, beccles and Colchester p. $385-412$.

[5] Balbaa, S.I.; Zaki, A.Y. and El-Zalabani, S.M. (1975): "preliminary phytochemical study of anthemis psendocotula bioss". Egypt. J. Pharm. Sci. 16: 323.

[6] Jenkins, D.J.A.; Gofh, D.V.; Leeds, A.R.; Alsert, K.G.M.M.; Wolever, T.M.S,; Gassull, M.A. and Hockaday. T.O.R. (1976): "Unabsorble carbohydrate and diabetes decrease post-prandial hyperglycemia" The Lance, 24: 172.

[7] Shani, JM. Goldschmied, A.; Joseph, B.; Ahroson, Z. and Suleiman, FG. (1974): "Hypoglycemic effect of trigonella-foenum graceum and Lupinus albus leguminosae seeds and their major alkaloids in alloxan diabetic and normal rats" . Intern. Pharmacodyn. Ther., 210: 27-37.

[8] Eskander, EF. and Won Jun, H. (1995): "Hpoglycemic and hyperinsulinemic. Effect of some Egyptian herbs used for treatment of diabetes mellitus (type II) in rats". Egypt. J. Pharm. Sci. 36: (1-6): 331-342.

[9] Mishkinisky, J., Joseph, B., Sulman, FG. and Al-Gold Schmied, A. (1967): "Hypoglycemic effect of Trigonelline". The lancet 16: 1311.

[10] Keys, JD. (1976): "Chinese herbs. Their botany chemistry and pharmacodynamic". Charles, E. and
Tuttle. Co. editors. Rutland vermoont Tokyo, press Japan, p. 127.

[11]Al-Awadi, F.; Khattar, MA. and Gomaa, KA. (1985): "On the mechanism of hypoglycemic effect of plant extract". Diabetologia 28: 432-434.

[12] Al-Hader, A.; Aqel, M. and Hasan, Z. (1993): 'Hypoglycemic and insulin release inhibitory effects of Rosmarinus officinalis". Int. J. Pharmacog. 31: 96-100.

[13] Doumas B. T. (1975): Standards for total serum protein assays--a collaborative study. Clin. Chem., 7: 175

[14] Trinder P (1969): An improved colour reagent for the determination of blood glucose by the oxidase system. Ann. Clin. Biochem. 6, 24.

[15]Reitman S and Frankel, S (1957): Calorimeteric determination of glutamate oxaloacetate transaminase and glutamate pyruvate transaminase activity. Amer J. Clin. Path., 28: 56.

[16] Patton, CJ. and Crouch, S.R. Spectrophotometeric and kinetic investigation of the berthelot reaction for the determination of ammonia.(1977): Anal. Chem. 49: 464-469.

[17] Henry, RJ. (1974): Clinical Chemistry. Principles and Technics, 2 nd Edition, Harper and Row, P, 525.

[18] Young, D. and Pestaner, L (1975): Effects of drugs on clinical laboratory tests. Clin Chem, 21, 5.

[19]Deeg R. and Ziegenohm, J (1982): Kinetic enzymic method for automated determination of total cholesterol in serum. Clin Chem 28: 1574.

[20] Mason R. D. (1976): In "Essential of Statistics Practice" Inc Englwood Cliff, New Jersy.

[21] Srivastava, Y,; Venkatakrishna-Bhatt, H. and Verma, Y. (1988): "Effect of Momordica charantia Linn. Pomous aqueous extract on cataractogenesis in murrin alloxan diabetics". Pharmcological Research Communications 20 (3) : 201 - 209.

[22] Roman, R.R.; Lara, L.A.; Alarcon, A.F. and Flores, S.J. (1992): "Hypoglycemic activity of some anti-diabetic plants". Archives of Medical Research, 23 (3): 105-109.

\section{Volume 5 Issue 5, May 2016}




\section{International Journal of Science and Research (IJSR) \\ ISSN (Online): 2319-7064}

Index Copernicus Value (2013): 6.14 | Impact Factor (2015): 6.391

[23] Sheweita SA., Newairy AA., Mansour, HA., and Yousef MI., (2002): Effect of some hypoglycemic herbs on the activity of phase I and II drug-metabolizing enzymes in alloxan-induced diabetic rats. Toxicology May 24; 174(2): 131-9.

[24] Cruickshank, A.H. (1954): J. Path. Bacteriaol., 76: 227.

[25] Helmi, R.; El-Mahdy, HA. and Khayyal, MAH. (1969): "Preliminary report on the hypoglycemic effect of Trifolium alexandrium and lupinus albus in animal and man" J. Egypt. Med. Ass. 52: 538-551.

[26] Kiliani, AI., Ibraheem, FK., Kamel, NA., Hareed, MA., Ali, AA. And Shahwan, MM. (1990): Proceeding of eighth annual scientific conference. Assiuut-Univ, March.

[27] Ammar, NM., Sahar, Y., Al-Okbi and Ibrahim, HB. (1995): The hypoglycemic effect of different extracts of Ambrosia maritima L. compositae. Egypt. J. Pharm. Sci. 365 (1-6): 107-115.

[28] Ribes, G.; Sauvaire, Y.; Baccou, JC.; Valette, G.; Chenon, D., Trimble, ER.. and Loubatieres-Mariani, MM. (1984): Effect of Fenugreek seeds on endocrine pancreatic secretion in dogs. Ann. Nutr. Metab. 28: 3743.

[29] Sharma, RD. (1986) An evaluation of hypocholesterolemic factor of fenugreek seeds. Nutr. Rep. Int. 33(4): 669-77.

[30] Riyad, MA.; Abdel-Ghani Abdel-Salam, S. and Suleiman, MS. (1987): Effect of fenugreek and/upine seeds on the development of experimental diabetes in rats. Planta medica 12: 286-289.

[31] Sauvaire, Y. and Ribes, G. (1992): Pharmaceutical composition containing mono or polyhydroxylated amino acids for treatment of non-insulin dependent diabetes mellitus. Eur. Pat. Appl. 195: 15-17.

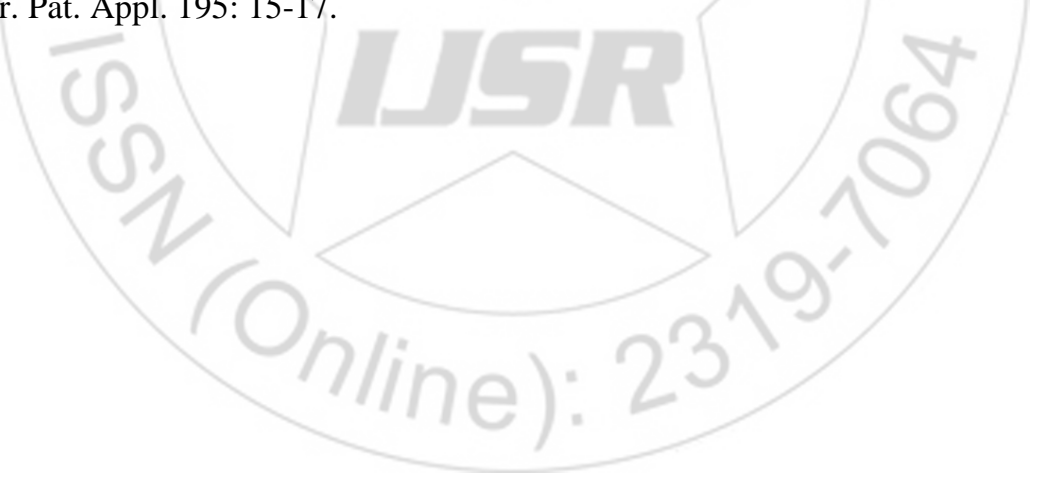

